\title{
Improvement and Innovation Analysis of China Special Express Mode-The Campus Express*
}

\author{
Xiuli Tang, Fangwen Yang, Rui Wang \\ Beijing Wuzi University, Beijing, China \\ Email: 513951730@qq.com
}

Received 27 July 2016; accepted 21 August 2016; published 24 August 2016

Copyright (C) 2016 by authors and Scientific Research Publishing Inc.

This work is licensed under the Creative Commons Attribution International License (CC BY). http://creativecommons.org/licenses/by/4.0/

(c) (i) Open Access

\begin{abstract}
This paper analyzes the current situation of the Campus Express mode through the quantitative and qualitative methods to find the deficiencies in the existing model, and puts forward the improvement of the existing Campus Express mode. A new sorting method is adopted in the Campus unified distribution center for improving picking efficiency and solving the problem of "door-todoor" service. At the same time, the Platform of Campus Express-named "Crowdsourcing Express" mode is created, so that everyone can be involved in the activities of Campus Express. The plant can not only provide a better logistics service, but also combine commerce activities with Campus Express.
\end{abstract}

\section{Keywords}

The Campus Express, “Door-to-Door” Service, “Crowdsourcing Express” Mode, Express Service

\section{Introduction}

The Campus Express is occurred in Chinese campus because of the rapid development of electronic commerce and college students are easy to accept new things. We called the Express service for campus- "the Campus Express”. At present, kinds of express companies are responsible for the management of the Campus Express, so resources of management are scattered. In order to solve the problems of the management of the Campus Express, make the environment of university clean and tidy, let teachers and students take package at a right time, do better in integrating the resources of Campus Express and make the distribution more efficient, we start ana-

\footnotetext{
*Project fund support: Beijing Municipal Science and technology project-Beijing city joint distribution key technology research, NO.
} Z121106002512043. 
lyzing the model of Campus Express existed now and making some research about new and more suitable models of the Campus Express.

We analyze the disadvantages of the models about Campus Express, and we propose to establish a platform to share information. We create a new method to sort package-named "Information matching mode", and provide "door-to-door" service to students. Through the construction of the campus express platform, we can make the inactive mode transform to active model that everyone can participate in. What's more, we integrate delivery model of Campus Express into new commodity.

By improving the delivery model of Campus Express, we can solve the problem that Campus Express makes the negative effect on campus environment, enhance the operational efficiency of the Campus Express, improve service quality and give teachers and students better and more effective service. As do like these ways, we can also set up a good image of campus.

\section{A Brief Introduction to the Current Model of the Campus Express}

With the development of electronic commerce, the number of students who have online shopping is rising sharply. Now, the students living in the campus has already become the main force of online shopping. This phenomenon does not only give the Campus Express too many challenges, but also stimulate the development of it.

\subsection{Express Company Decentralized Distribution}

At present, the most extensive distribution mode in Campus Express is the express company decentralized distribution [1]. Various express companies after the receipt of the express mail using small delivery vehicles will express respectively from operating outlets sent to colleges and universities. Couriers according to the information of express mail call the recipient phone and notify the recipient. Couriers usually stack lots of packages in front of Campus's gate. Doing like these makes the environment look like very chaotic, sometimes, there are some packages lost. At the same time, students or teacher cannot check their packages if well or not.

\subsection{Building Self-Service Container}

On the base of express company in decentralized distribution, some colleges built self-service container on the campus. Each express courier first sent packages to campus, then they will put them into the container [2]. Finally, through the mobile phone, container password is sent to the recipient's phone on, at the same time, the recipient according to the password go to the container to pick up their courier. Self-service containers are often built in the vicinity of the campus dormitory or dining room for students to pick up their package.

\subsection{Building Distribution Center in Campus}

We have introduced two kinds of model about Campus Express, and then I can tell you the most favored model is that universities establish a Distribution Center in Campus. There is often a part of idle housing in our universities by establishing Distribution Center in our campus. The main operation mode:

1) Students as the main body negotiate with school about renting the idle house [2]. Students can build the Distribution Center as their Entrepreneurial projects, meanwhile, they can work with the express companies, in support of the school, to help the express companies deliver packages with Distribution Center in campus.

2) The universities as the main body build the Distribution Center, in order to keep the environment of campus beautiful, to provide better service to teachers and students. What's more, the universities can have unified management in Campus express.

\section{The Summary of Shortcoming about Three Modes of Campus Express}

\subsection{The Existing Model Can Not Meet the Requirements of the Door-to-Door Service and Convenience is Limited}

We can see the advantages and disadvantages of the three modes by the following Table 1 .

The first disadvantage is the low efficiency of picking. The mode of decentralized distribution doesn't include sorting the packages; it just can be called “discharge cargo". Although the mode of self-service container and 
Table 1. The table about the advantages and disadvantages of Campus express ${ }^{1}$.

\begin{tabular}{ccccc}
\hline & The delivery time & Door-to-door service & Cost & The number of packages delivered \\
\hline $\begin{array}{c}\text { Express company } \\
\text { decentralized distribution } \\
\begin{array}{c}\text { Building Self-service } \\
\text { container }\end{array}\end{array}$ & Average $30-45 \mathrm{~min}$ & $\mathrm{X}$ & $3000 \mathrm{RMB} / \mathrm{month}$ & Average $150-200$ \\
$\begin{array}{c}\text { Building Distribution } \\
\text { Center } \text { in campus }\end{array}$ & Average $20-35 \mathrm{~min}$ & $\mathrm{X}$ & $2500 \mathrm{RMB} / \mathrm{month}$ & Average $200-300$ \\
\hline
\end{tabular}

Distribution Center need to sort first, the time of sorting is too long and the efficiency is too low.

The second disadvantage is that the current distribution model can't provide the "door-to-door service” for students or teachers. Even building Distribution Center in campus in the campus, it just lets students pick their own packages, not provide the service.

The third disadvantage is that the cost of Building Self-service container is relatively high. Now the all of distribution center in campus use the self-service container, compared with the normal shelf in terms of cost more and more occupied storage space.

For the three kinds of the existing models, we should firstly choose ways to optimize and improve the efficiency of sorting, reduce the workload, increase the door-to-door service, extending the campus Courier services, and give the better service to students and teachers.

\subsection{Existing Models to the "Passive" Distribution, Demand Is Not Fully Excavated}

By the analysis of three kinds of modes and found that at present, the main delivery mode of Campus Express is "passive" distribution. This "passive" delivery mode is lack of participants, only express courier as a delivery task. The students just wait for express company to deliver the goods to the campus, and then pick up. However, sometimes students also need to send packages by express, they can only call and inform the express company to send their package. Students have no another way to send their packages and letters. So we can say, the model of express campus is lack of channels to meet students' demand.

At the same time, some potential logistics activities are existing inside campus [3]. For example: help to buy water, call a carry-out, buy some things out of school and so on, like these express activities, express company is not responsible for that. The "Passive" delivery mode is lack of the flow of commerce, we should let logistics joined in the business flow, to accelerate the flow of commerce logistics distribution, increase the logistics activity, increase of logistics services and the breadth, to better meet the needs of teachers and students needs.

\section{Improvement and Innovation Analysis of the Mode of Campus Express}

\subsection{Improvement for Existing Express Delivery Mode-The New Sorting Method}

\section{Introduction of the New Sorting Method}

The new sorting method is establishing a new “information matching” plant. This plant collects some personal information which includes the student ID; Name; telephone number and dormitory number. At the same time, this plant also gets the information on the waybill.

The function of the new mode mainly has three parts: Information matching and integration, intelligent location, monitoring and predicting the preference of the recipient. Firstly, Information matching means that we match dormitory number with the personal information on the waybill. Therefore, we can know where the recipients live and provide the “door-to-door” service to them (Figure 1).

Intelligent location system means that using intelligent speech recognition system records the information about the number of express and the location of packages. When someone comes to pick up the package, he can tell system the number of express. Then, the system will lead him to find packages. Using intelligent speech recognition system can make the sorting uninhibited by the shelf. Not only improving the efficiency of sorting and make "random stacking", but also can improve the collection efficiency and accurate positioning, Because of these system, we don't need to build “self-service container” in distribution center of campus, it's enough for us to adopt a common type shelf. Like do this, we can reduce the cost of "Self-service container" and improve

\footnotetext{
${ }^{1}$ Data source: we visit a lot of campus in Beijing and collect these data.
} 


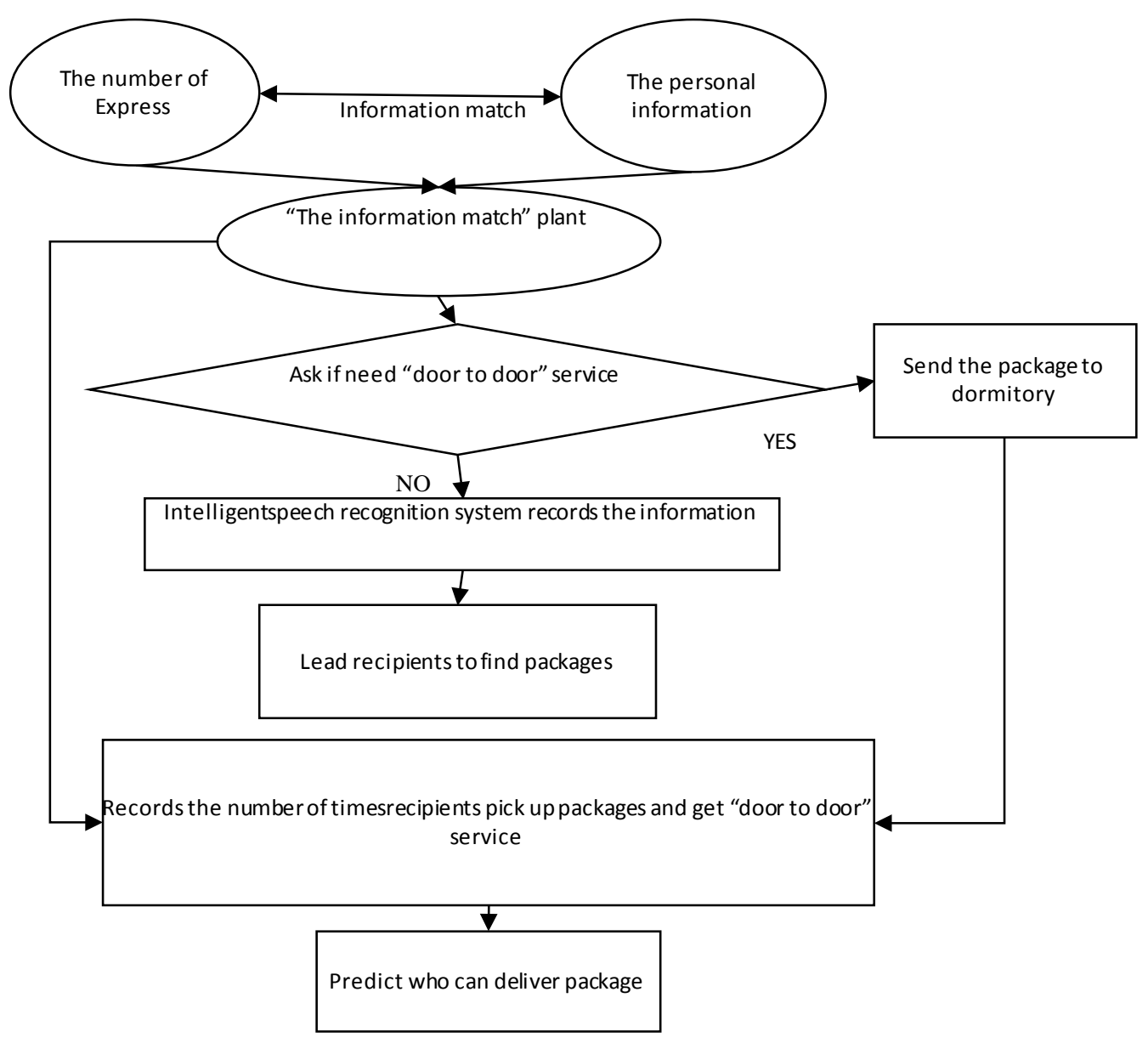

Figure 1. The procedure of new sorting method.

the accuracy of finding packages in distribution center.

What's more, the platform also records the number of times that recipients have picked up packages by himself and he get the "door-to-door" service. At the same time, according to the information, the plant will predict which students can help the staffs, in distribution center, deliver the packages when they pick up their packages. If someone wants to help them deliver some packages, they can get some fees.

\subsection{Innovation for Existing Express Delivery Mode-“Crowdsourcing Express" Mode}

The "Crowdsourcing" is defined by Merriam-Webster as the process of obtaining needed services, ideas, or content by soliciting contributions from a large group of people, especially an online community, rather than from employees or suppliers ${ }^{2}$. The "Crowdsourcing Express" means that let more people take participate in express activities. This mode is established on a mobile app, using this app that makes everyone can participate in the Campus Express. Whoever you are teachers or students, you can participate in the activities of Campus Express, you can deliver packages as a courier or you can send information on it to get "door-to-door" service. This app can be designed by students as their venture project or let some software company design it. During this mode is operating, the campus must keep watch on the activities. If there is an economic dispute happened, the campus will do some negotiation and mediation between students.

The function of "Crowdsourcing Express" mode includes: commodity trading function, the express function everyone can be involved in, online payment function, the demand predict function.

The commodity function can meet any potential demand in Campus, such as: buy some food for dinner, get goods from market which is far from you, ask someone to send your packages to your dormitory and so on. The 
existing mode can't provide this service for students or teachers. Through this app, everyone can send their requirement on it as an order, if someone wants to earn some money, he will accept this order to finish it for you. This new mode adds business to Campus Express to meet the potential demand and provide more value-added services for students or teachers (Figure 2).

At the same time, you can pay for orders online by "Alipay" or "Wechat-pay" [4]. Through the app, we can experience all business and logistics activities online [1]. What's more, you also can get these services from offline. You can get express service from distribution center in campus and buy some food in campus store.

When you use the app to make an order, you will leave your information on it. So, the app uses the information to build a data base and adopts some technologies of big data processing and analysis to forecast what the students want to buy. We will send our forecast data to some markets around us; the information can help them know which kind of good is in a lot of demand. These markets can change the purchase strategy to reduce inventory costs.

With the commerce combination with Campus Express, the commerce stimulates the development of Campus Express. Meanwhile, this mode make "passive" express activities transfer to "active" express activities, everyone can take participate in Campus express mode, enhance the vitality of campus express, creating more value-added campus express services.

\section{Model Evaluation Based on Fuzzy Synthetic Evaluation}

\subsection{Establishment of Fuzzy Synthetic Evaluation System}

The improvement and innovation mode has been adopted by some campus in china, so I use fuzzy synthetic evaluation to evaluate the performance of the new model. First, I establish evaluation index of fuzzy synthetic evaluation and ensure four grades.

$$
V=\left(V_{1}, V_{2}, V_{3}, V_{4}\right)=(\text { Better, Good, Bad, Worse })
$$

After that, we invited 20 experts to mark according to the evaluation index, the full mark is 10 . Then, we average these scores and make the later Table 2.

\subsection{Calculating Fuzzy Synthetic Evaluation System}

Firstly, we establish first level fuzzy comprehensive evaluation. This level is that Criterion level makes judgment to Index level and get conclusion $\left(V_{k}\right)$ which in degree of membership is

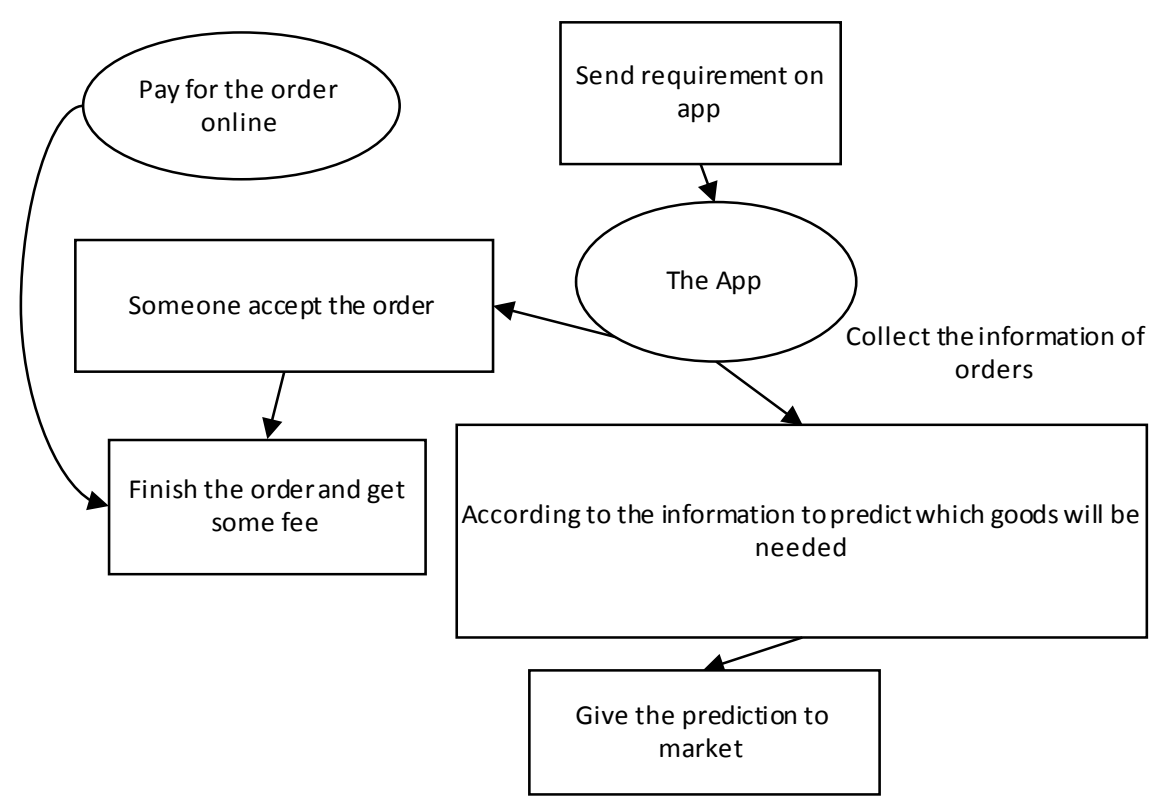

Figure 2. The procedure of the crowdsourcing Express mode. 
Table 2. The point table of fuzzy synthetic evaluation.

\begin{tabular}{|c|c|c|c|c|c|c|}
\hline Target level & Criterion level & Index level & Better & Good & Bad & Worse \\
\hline \multirow{16}{*}{$\begin{array}{c}\text { The improvement } \\
\text { and innovation } \\
\text { mode }\end{array}$} & \multirow{4}{*}{$\begin{array}{c}\text { The new information } \\
\text { plant }\end{array}$} & Information match & 8 & 5 & 2 & 3 \\
\hline & & Intelligent speech recognition & 8 & 6 & 2 & 2 \\
\hline & & Intelligent location positioning & 7 & 7 & 2 & 2 \\
\hline & & Voice pickup & 5 & 6 & 1 & 2 \\
\hline & \multirow{5}{*}{ The new sorting method } & Provide door-to-door service & 7 & 6 & 3 & 3 \\
\hline & & Packages can be Random placed on shelf & 6 & 4 & 2 & 3 \\
\hline & & Reduce the number of employees & 7 & 6 & 3 & 2 \\
\hline & & Giving the opportunity of earning fees & 7 & 4 & 2 & 1 \\
\hline & & buy on sb.'s behalf & 8 & 7 & 3 & 2 \\
\hline & \multirow{4}{*}{$\begin{array}{c}\text { The value-added service } \\
\text { of Crowdsourcing } \\
\text { express }\end{array}$} & On the behalf of sending packages & 7 & 7 & 2 & 2 \\
\hline & & Payment online & 9 & 7 & 2 & 3 \\
\hline & & Big luggage transportation & 7 & 5 & 3 & 1 \\
\hline & & The forecast for demand & 6 & 9 & 3 & 2 \\
\hline & \multirow{3}{*}{$\begin{array}{c}\text { The other information } \\
\text { service }\end{array}$} & Provide more express information in campus & 7 & 6 & 3 & 2 \\
\hline & & Integrate information resources in campus & 9 & 4 & 2 & 3 \\
\hline & & $\begin{array}{l}\text { Make more people take participate in } \\
\text { express activities }\end{array}$ & 8 & 7 & 4 & 2 \\
\hline
\end{tabular}

$r_{i j k}(i=1,2,3, \cdots, n, j=1,2,3, \cdots, m, k=1,2,3, \cdots, z)$. So, judgment matrix can be expressed as

$$
R_{i}=\left(\begin{array}{c}
R_{i 1} \\
R_{i 2} \\
R_{i 3} \\
\vdots \\
R_{i m}
\end{array}\right)=\left(\begin{array}{cccc}
r_{i 11} & r_{i 12} & \cdots & r_{i 1 p} \\
r_{i 21} & r_{i 22} & \cdots & r_{i 2 p} \\
\vdots & \vdots & \ddots & \vdots \\
r_{i m 1} & r_{i m 2} & \cdots & r_{i m p}
\end{array}\right)
$$

So, we can get $B_{i}=W_{i} * R_{i}=\left(b_{i k}\right), b_{i k}=\sum_{j=1}^{m} w_{i k} r_{i j k}(i=1,2 \cdots, n, k=1,2 \cdots, p)$. $W_{i}$ means weight coefficient, in this paper we cited a paper and decide it value as $W_{i}=(0.3,0.3,0.2,0.2)^{3}$.

After finish establishing first level, we start establishing second level. This level is about that Target level makes judgment to Criterion level.

$$
R=\left(\begin{array}{c}
B_{1} \\
B_{2} \\
\vdots \\
B_{n}
\end{array}\right)=\left(\begin{array}{c}
w_{1} * r_{1} \\
w_{2} * r_{2} \\
\vdots \\
w_{n} * r_{n}
\end{array}\right)=\left(b_{1}, b_{2}, b_{3}, \cdots, b_{k}, \cdots, b_{p}\right)(k=1,2, \cdots, p)
$$

So, we can calculate to get conclusion.

$$
\begin{aligned}
& B_{1}=(0.42,0.35,0.1,0.13) \\
& B_{2}=(0.41,0.30,0.15,0.14) \\
& B_{3}=(0.41,0.35,0.13,0.10) \\
& B_{4}=(0.38,0.35,0.16,0.12)
\end{aligned}
$$

${ }^{3} \mathrm{Hu}$ Xiaozhao researched on the integration of campus online shopping logistics based on the theory of integrated field theory—Take Xi'an Eurasia University as an example. 
Single factor matrix is $B=\left(B_{1}, B_{2}, B_{3}, B_{4}\right)$, therefore, the Evaluation matrix is $A_{1}=(\omega * B)$

$$
A_{1}=(0.3,0.3,0.2,0.2)\left(\begin{array}{llll}
0.49 & 0.36 & 0.03 & 0.12 \\
0.36 & 0.33 & 0.08 & 0.08 \\
0.44 & 0.38 & 0.14 & 0.03 \\
0.43 & 0.40 & 0.10 & 0.07
\end{array}\right)=(0.48,0.36,0.08,0.08)
$$

According to the principle of maximum membership degree, the good and better level achieves 0.74 , we can think that the model has better performance in operation.

\section{Conclusion}

In China, because of the rapid development of electronic commerce and for college students are easy to accept new things and the increase number of packages delivered to campus, the Campus Express mode happened in China. The campus express belongs to distribution of the last mile in the city, so improving this mode does not only provide better express service for students or teachers, but also provide a new idea to solve the problem of distribution of the last mile in the city. To provide more value-added service and better express service, we believe that "Crowdsourcing Express" mode will become a trend in the future, and more and more university will adopt this mode.

\section{References}

[1] Cheng, G., Sun, P.-Y., Wang, W., Cao, C.-M. and Tang, F. (2014) The Optimization of Signing for Express Representatively-Jiangnan University Major as Example. Logistics Sci-Tech, 9, 111-114.

[2] Gu, Z., Shan, X.X., Zou, Y.Q., Zhou, X.F. and Lu, X. (2014) The Feasibility Study on the Establishment of Express Supermarket in the University Campus In the Case of Universities of Nanjing. Logistics Engineering and Management, 36, 151-152

[3] Wang, J.L., Yang, H., Xu, S.M. and Ru, Y.H. (2015) Study on Express Integrated Station in Beijing's Universities with the Delivery Mode of Public Participation. Logistics Engineering and Management, 37, 6-7.

[4] Ren, D.Y. (2014) Study on University On-Campus Express Service System on Wechat Platform. Logistics technology, 33, 62-64.

[5] Hu, X.Z. (2015) Research on the Integration of Campus Online Shopping Logistics Based on the Theory of Integrated Field Theory-Take Xi'an Eurasia University as an Example. PG. Thesis, Chang'an University, Xi'an.

\section{Submit or recommend next manuscript to SCIRP and we will provide best service for you:}

Accepting pre-submission inquiries through Email, Facebook, LinkedIn, Twitter, etc.

A wide selection of journals (inclusive of 9 subjects, more than 200 journals)

Providing 24-hour high-quality service

User-friendly online submission system

Fair and swift peer-review system

Efficient typesetting and proofreading procedure

Display of the result of downloads and visits, as well as the number of cited articles

Maximum dissemination of your research work

Submit your manuscript at: http://papersubmission.scirp.org/ 